\title{
Temporal distribution of fruit-feeding butterflies (Lepidoptera, Nymphalidae) in the eastern extreme of the Amazon region
}

\author{
Elias da Costa ARAUJO ${ }^{1,2,3 *}$, Lucas Pereira MARTINS ${ }^{1}$, Marcelo DUARTE ${ }^{3}$, Gisele Garcia AZEVEDO ${ }^{1}$ \\ Universidade Federal do Maranhão (UFMA), Departamento de Biologia (DEBIO), Laboratório de Ecologia e Sistemática de Insetos Polinizadores e Predadores \\ (LESPP). Avenida dos Portugueses, 1966, Vila Bacanga, CEP 65080-805, São Luís, MA, Brazil \\ 2 Universidade de São Paulo (USP), Instituto de Biociências (IB), Departamento de Zoologia, Programa de Pós-Graduação em Ciências Biológicas (Zoologia). Rua do \\ Matão, travessa 14, número 321, Butantã, CEP 05508-900 São Paulo, SP, Brazil \\ 3 Universidade de São Paulo (USP), Museu de Zoologia (MZUSP). Avenida Nazaré 481, Ipiranga, CEP 04263-000, São Paulo, SP, Brazil \\ * Corresponding author: elias.araujr@gmail.com; (D) https://orcid.org/0000-0003-1764-5086
}

\begin{abstract}
Rainfall is one of the most influential factors driving insect seasonality in the Amazon region. However, few studies have analyzed the temporal dynamics of fruit-feeding butterflies in the Brazilian Amazon, specially in its eastern portion. Here, we evaluated the diversity patterns and temporal distribution of fruit-feeding butterflies in a remnant of eastern Amazon forest in the Baixada Maranhense, northeastern Brazil. Specifically, we tested whether fruit-feeding butterflies are temporally structured and whether rainfall influences species richness and abundance. Butterflies were collected with baited traps in both the rainy and dry seasons for two consecutive years. In total, we captured 493 butterflies belonging to 28 species, 15 genera and eight tribes. Three species comprised about half of the overall abundance, and Satyrinae was the most representative subfamily. The fruit-feeding butterfly assemblage showed a strong temporal structure during the second year of sampling, but not during the first year. Species composition and richness did not differ between rainy and dry seasons, and neither abundance nor richness was influenced by rainfall. Our results indicate that seasonality is not a strong environmental filter in this region, and that other biotic and abiotic factors are probably driving the community structure. The predominance of palms in the Baixada Maranhense, which are used as host plants by larvae of several lepidopteran species (specially satyrines) and are available yearround, might have contributed to the observed patterns of temporal diversity.
\end{abstract}

KEYWORDS: Brazilian Amazon, frugivorous butterflies, Maranhão, seasonality, temporal diversity, tropical forest

\section{Distribuição temporal de borboletas frugívoras (Lepidoptera, Nymphalidae) no extremo leste da região amazônica}

\section{RESUMO}

A pluviosidade é considerada um dos fatores mais determinantes na sazonalidade de insetos na regiáo amazônica. No entanto, poucos estudos analisaram a dinâmica temporal de borboletas frugívoras na Amazônia brasileira, especialmente em sua porção oriental. Aqui, avaliamos os padrôes de diversidade e a distribuição temporal de borboletas frugívoras em um remanescente de floresta amazônica oriental na Baixada Maranhense, nordeste do Brasil. Especificamente, testamos se borboletas frugívoras são temporalmente estruturadas e se a pluviosidade influencia a riqueza e abundância das espécies. As borboletas foram coletadas com armadilhas iscadas nas estaçóes chuvosa e seca por dois anos consecutivos. No total, capturamos 493 borboletas pertencentes a 28 espécies, 15 gêneros e oito tribos. Três espécies representaram cerca da metade da abundância total, e Satyrinae foi a subfamília mais representativa. A assembleia de borboletas frugívoras apresentou uma forte estrutura temporal durante o segundo ano de amostragem, mas não durante o primeiro ano. A composição e riqueza de espécies não diferiram entre as estaçôes chuvosa e seca, e tanto a abundância quanto a riqueza não foram influenciadas pela chuva. Nossos resultados indicam que a sazonalidade não é um filtro ambiental forte na regiấo estudada, e que outros fatores bióticos e abióticos provavelmente determinam a estrutura da comunidade. A predominância de palmeiras na Baixada Maranhense, que são utilizadas como plantas hospedeiras por larvas de várias espécies de lepidópteros (especialmente satiríneos) e estão disponíveis durante todo o ano, pode ter contribuído para os padróes observados de diversidade temporal.

PALAVRAS-CHAVE: Amazônia brasileira, borboletas frugívoras, Maranhão, sazonalidade, diversidade temporal, floresta tropical 


\section{INTRODUCTION}

The effects of environmental conditions on species diversity have long been of interest in ecology (MacArthur 1964; Huston 1979). Environmental parameters, such as rainfall and temperature, contribute not only to the understanding of how species are distributed in space, but also how species and their interactions vary through time (Chesson 2000; Tonkin et al. 2017). Typically, insects are considered excellent models for the study of seasonal influences on species richness and abundance due to their short generation times (Devries et al. 1997; Grøtan et al. 2014) and rapid responses to environmental changes (Scherrer et al. 2013). Although seasonality is a relatively well-studied phenomenon in insect biology (Wolda 1978; Wolda 1988), its underlying causes and mechanisms are still not completely understood (KishimotoYamada and Itioka 2015). An array of different factors can drive seasonal changes or even long-term stability in insects (Chiquetto-Machado et al. 2018), and the importance of these factors may vary depending on the taxonomic group (Wolda 1988; Pinheiro et al. 2002; Scherrer et al. 2013).

The Amazon Basin includes the largest remaining area of tropical rainforest in the world (Foley et al. 2007), harboring a considerable biological diversity. Rainfall is considered one of the most important abiotic factors shaping Amazonian biodiversity (Moraes et al. 2005), and seasonal variations have been demonstrated for different insect groups in the region (Lucky et al. 2002; Frederickson 2006; Valente et al. 2018). Seasonality in the Amazon is determined by the annual distribution of rainfall, and two distinct seasons are considered to occur in this biome: the rainy season, which is characterized by intense rainfalls, and the dry season, which is characterized by frequent droughts of variable duration (Moraes et al. 2005). These periods can generate seasonal patterns in the availability of important food resources (e.g. leaves, flowers and fruits), which may have a cascade effect through the trophic chain and directly affect insect abundance and composition (Wolda 1988).

Among insect groups, fruit-feeding butterflies (family Nymphalidae: subfamilies Satyrinae, Charaxinae, Biblidinae and some members of Nymphalinae) have a well established taxonomy and are commonly used as ecological models, including studies on forest fragmentation (Uehara-Prado et al. 2005; Uehara-Prado et al. 2007; Sant'Anna et al. 2014), vertical stratification (DeVries et al. 1997; Ribeiro and Freitas 2012), insect-plant interactions (Ehrlich and Raven 1965; Muniz et al. 2012), temporal and spatial diversity (DeVries and Walla 2001; Checa et al. 2013) and seasonality (Pozo et al. 2008; Ribeiro and Freitas 2011; Nobre et al. 2012; Freire Júnior and Diniz 2015). The temporal dynamics of this group is relatively well known in the Brazilian Atlantic Forest (e.g. Ribeiro et al. 2010), but not in other Brazilian biomes. Studies of the effects of environmental variables on the structure of Amazonian assemblages of fruit-feeding butterflies are relatively few (but see Ramos 2000; Barlow et al. 2007; Ribeiro and Freitas 2012; Teston and Silva 2017), and there are still no records of butterfly diversity and distribution for extensive areas of the region.

The eastern Amazon represents one of the major gaps in biodiversity knowledge in Brazil, and is considered a priority area for biodiversity conservation due to the high rate of deforestation and loss of endemic species in this region (Martins and Oliveira 2011; Valente et al. 2018). In the state of Maranhão, in northeastern Brazil, the primary Amazon Forest areas have undergone intense modification in recent decades, mainly due to increased demand for pasture and timber, and the expansion of the agricultural frontier. Despite this accelerated deforestation and forest fragmentation, the Amazon forest remnants in Maranhão still host a diversified, yet poorly known biota (Martins and Oliveira 2011). Among these remnants, the Baixada Maranhense Environmental Protection Area (hereafter, Baixada Maranhense), located in the northern part of the state, contains a rich fauna and flora (Costa Neto et al. 2002; Martins et al. 2017a; Pinheiro et al. 2005; Pereira et al. 2007; Pinheiro et al. 2010; Pereira 2012). The vegetation of this region is composed of secondary forests in different successional stages, riparian forests, floodplains, palm forests and remnants of primary forests (Pinheiro et al. 2010). The rainfall regime in the Baixada Maranhense is strongly seasonal, which causes large cyclical changes in the water level of its extensive floodplains and lakes. Despite the effects of anthropic disturbances in the Baixada Maranhense, this area is still considered ideal for studies of fruit-feeding butterfly diversity and seasonality, given the scarcity of data on this group in the region (Martins et al. 2017a).

In this study, we investigated the diversity patterns and temporal distribution of fruit-feeding butterflies during two years in a remnant of eastern Amazon forest in the Baixada Maranhense. Specifically, we addressed the following questions: (1) How do the abundance and richness of fruit-feeding butterflies fluctuate over time? (2) Do species composition and richness of fruit-feeding butterflies change between the rainy and dry seasons? and (3) Are abundance and richness of fruit-feeding butterflies positively related to rainfall? Considering that previous studies have found a marked seasonality in fruit-feeding butterfly assemblages (Pozo et al. 2008; Ribeiro et al. 2010; Nobre et al. 2012), we expected to find a wide fluctuation in butterfly abundance and species richness over time. Similarly, we expected that species composition and richness would change between seasons. Lastly, considering that the availability and quality of fruit-feeding butterfly resources (e.g. leaves during the larval stage and rotting fruits during the adult stage) usually vary according to the rainfall cycle (Rathcke and Lacey 1985; Wolda 1988), we expected that butterfly abundance and species richness would be positively related to rainfall. 


\section{MATERIAL AND METHODS}

\section{Study area}

Fieldwork was carried out from 2013 to 2015 in Parque Agroecológico Buritirana (hereafter, PAB) $\left(02^{\circ} 38^{\prime} 22^{\prime \prime}\right.$, $044^{\circ} 50^{\prime} 51^{\prime \prime} \mathrm{W}$ ), an environmental protection area of approximately 600 ha located in the eastern extreme of the Amazon region, in the municipality of Peri Mirim, Maranhão state, Brazil (Figure 1). Annual precipitation ranges from
1700 to $2000 \mathrm{~mm}$, with approximately $90 \%$ of the rainfall occurring in the first six months of the year (rainy season). The climate is humid and megathermal, with a hydric deficit in the last six months of the year (dry season). The annual mean temperature is approximately $27^{\circ} \mathrm{C}$ (Pereira 2012). Abiotic data were obtained through the meteorological station of Universidade Estadual do Maranhão (UEMA).
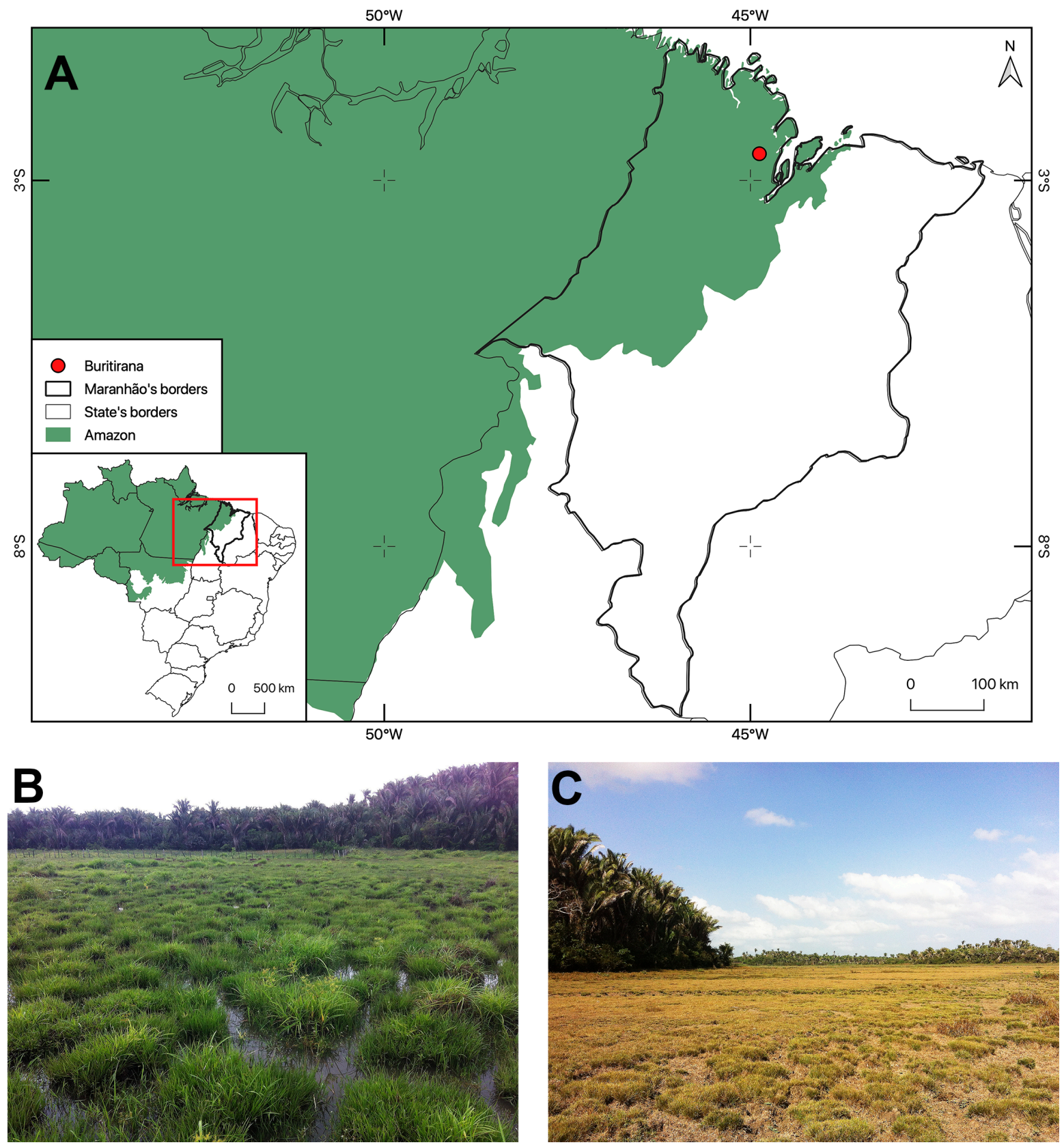

Figure 1. Location of the study area (Parque Agroecológico Buritirana) in the eastern Brazilian Amazon region (A). Floodplains are inundated during the first semester of the year (B) and dry during the second semester (C). This figure is in color in the electronic version. 
The topography is characterized by the absence of steep slopes, with the highest points around $30 \mathrm{~m}$ above sea level. Landscape units in the area are classified as floodplain and terra firme forest (Pinheiro et al. 2010). The extensive floodplains are flooded only during the first semester of the year, with subsequent development of grasses and sedges in the second semester (Figure 1). The terra firme forest is composed of secondary forests and monospecific forests of the babassu palm, Attalea speciosa Mart. ex. Spreng (Arecaceae). The canopy is predominantly open, while the understory is generally open in the areas dominated by $A$. specios $a$ and dense within the secondary forests. The secondary forests are subject to several anthropic impacts, such as clearings, trails and extensive farming, which indicate the process of forest conversion to pasture. The predominance of monospecific forests of $A$. speciosa in most of the PAB also indicates that this area has suffered environment impacts over the years, resulting in changes in the native vegetation (Pinheiro et al. 2013). In fact, this palm is generally found in low densities in mature rainforests, but is dominant on degraded land, specially throughout the eastern and southern peripheries of the Amazon region (Nobre et al. 2018).

\section{Sampling and species identification}

Fruit-feeding butterflies were sampled for two years in both seasons (rainy and dry), six sampling periods in each season per year, totalling 24 sampling campaigns, 12 per season. Intervals among sampling periods ranged from 25 to 35 days. We used 10 cylindrical traps of the Van Someren-Rydon type (Rydon 1964) in each sampling period to capture the butterflies. The traps were baited with a mixture of bananas and sugarcane fermented for $48 \mathrm{~h}$ (see DeVries et al. 1999) and suspended at 1 to 1.5 $\mathrm{m}$ above the ground (DeVries and Walla 2001; Uehara-Prado et al. 2005). We established one sampling site composed of a central transect $1,000 \mathrm{~m}$ long in terra firme forest, and placed traps every $200 \mathrm{~m}$ in pairs opposite each other, at a distance of $100 \mathrm{~m}$ from the transect. In each sampling period, the traps remained in the field for two consecutive days, for $33 \mathrm{~h}$ (from 8:00 to 17:00 the next day). We inspected the traps twice a day to retrieve captured specimens.

Butterflies were identified by comparison with specimens deposited at the Museu de Zoologia da Universidade de São Paulo (MZUSP) and the Museu de Zoologia da Universidade Estadual de Campinas (ZUEC) and through specialized catalogues (D'Abrera 1995, Garwood et al. 2009). In some cases, in addition to external morphological analysis, we dissected adult individuals to observe the genitalia, according to procedures described by Winter (2000). Identifications were confirmed by a taxonomist specialized in the group (André Victor Lucci Freitas). Vouchers are deposited in the collections of two institutions: Universidade Federal do Maranhão (LESPP/UFMA) and ZUEC.

\section{Statistical analysis}

We calculated the sample completeness of the overall fruitfeeding butterfly assemblage using the coverage-based estimator recommended by Chao and Jost (2012). This method is based on the proportion of the total number of individuals in an assemblage that belong to the species represented in the sample. To test the effect of seasonality on species richness, we generated sample-size and coverage-based extrapolation and rarefaction curves for each season, also following Chao and Jost (2012). An integrated sample-size or coverage-based curve includes the rarefaction portion, representing the species increment based on the real data, and the extrapolation portion, which estimates the species increment beyond the real number of captured individuals. Based on $95 \%$ confidence intervals, we can make direct comparisons of species richness using both the rarefied and extrapolated richness values, even if the assemblages have unequal abundances. Confidence intervals were generated using the bootstrap procedure with 50 replications. The curves were generated using the iNEXT package (Hsieh et al. 2019) in R (R Core Team 2019).

We analyzed the fluctuations in species richness and abundance over time by visually inspecting the graphs and tables. Circular analyses were then used to test whether butterfly abundance and richness are temporally structured. In this analysis, the date of capture of each specimen is transformed into degrees, and the mean vector $(\mathrm{m})$ and its length ( $r$ ) are calculated. The length of the mean vector represents how concentrated the species abundance or richness is throughout each year. We used Rayleigh's uniformity test to check if the annual distribution of the butterflies is uniform or grouped (Zar 1999). Circular analyses were performed in the software Oriana (Kovach Computing Services 2011).

To test if species composition differed between the rainy and dry seasons, we performed PERMANOVAs (Permutational Multivariate Analyses of Variance), using both the abundance-based Bray-Curtis and the presence-based Jaccard indices as our measures of dissimilarity. Then, we performed a NMDS (Non-metric Multidimensional Scaling) to visualize the overall differences in species composition between seasons. Both the PERMANOVA and NMDS were calculated using the vegan package (Oksanen et al. 2019) in $\mathrm{R}$ ( $\mathrm{R}$ Core Team 2019).

To test the effect of rainfall on species richness and abundance, we performed two Generalized Least Squares (GLS) models with temporal auto-correlation structures (Zuur 2009). In the first, rainfall $(\mathrm{mm})$ was used as the explanatory variable, and richness per sample was used as the response variable. In the second, rainfall $(\mathrm{mm})$ was used as the explanatory variable, and abundance per sample was used as the response variable. Rainfall was measured as the total rainfall during the month of collection. Models were generated using the nlme package (Pinheiro et al. 2018) in R (R Core Team 2019). 


\section{RESULTS}

In total, 493 individuals belonging to 28 species, 15 genera and 8 tribes were sampled during the two years of the study (Table 1). The sampling effort applied was sufficient to capture approximately $90 \%$ of the total species richness (31.2 estimated species in contrast to the 28 species that were actually collected). All known subfamilies of neotropical fruit-feeding butterflies were recorded (Table 2). Satyrinae (14 species, $50 \%$ of the overall richness) was the richest subfamily, followed by Charaxinae (seven species, 25\%), Biblidinae (four species, $14.3 \%$ ) and Nymphalinae (three species, 10.7\%). Satyrinae was also the most abundant subfamily, with 322 individuals (65\% of the fruit-feeding butterflies collected), followed by Biblidinae, with 83 (17\%), Charaxinae with

Table 1. Fruit-feeding butterfly species captured in Parque Agroecológico Buritirana (Maranhão state, eastern Brazilian Amazonia), showing the number of individuals captured per species and in each season (rainy and dry), the relative frequency of individuals per species, and the frequency of samples in which each species was present. The numbers after taxon names indicate the number of species in the taxon.

\begin{tabular}{|c|c|c|c|c|c|}
\hline \multirow{2}{*}{ Species } & \multicolumn{3}{|c|}{ Abundance } & \multicolumn{2}{|c|}{ Frequency (\%) } \\
\hline & Rainy season & Dry season & Total & Individuals/species & Samples/species \\
\hline \multicolumn{6}{|l|}{ Biblidinae (4) } \\
\hline \multicolumn{6}{|l|}{ Ageroniini (4) } \\
\hline Hamadryas amphinome amphinome (Linnaeus, 1767) & 7 & 2 & 9 & 1.8 & 25.0 \\
\hline Hamadryas chloe rhea (Fruhstorfer, 1907) & 41 & 17 & 58 & 11.8 & 83.3 \\
\hline Hamadryas februa februa (Hübner, [1823]) & 1 & 10 & 11 & 2.2 & 8.3 \\
\hline Hamadryas feronia feronia (Linnaeus, 1758) & 1 & 4 & 5 & 1.0 & 12.5 \\
\hline \multicolumn{6}{|l|}{ Charaxinae (8) } \\
\hline \multicolumn{6}{|l|}{ Anaeini (2) } \\
\hline Hypna clytemnestra clytemnestra (Cramer, 1777) & 3 & 0 & 3 & 0.6 & 12.5 \\
\hline Zaretis isidora (Cramer, 1779) & 24 & 11 & 35 & 7.0 & 70.8 \\
\hline \multicolumn{6}{|l|}{ Preponini (6) } \\
\hline Archaeoprepona demophoon demophoon (Hübner, [1814]) & 0 & 1 & 1 & 0.2 & 4.2 \\
\hline Archaeoprepona demophon demophon (Linnaeus, 1758) & 7 & 10 & 17 & 3.4 & 25.0 \\
\hline Prepona laertes laertes (Hübner, [1811]) & 0 & 2 & 2 & 0.4 & 8.3 \\
\hline Preponasp. & 0 & 6 & 6 & 1.2 & 20.8 \\
\hline Mesoprepona pheridamas (Cramer, 1777) & 6 & 4 & 10 & 2.0 & 29.2 \\
\hline \multicolumn{6}{|l|}{ Nymphalinae (3) } \\
\hline \multicolumn{6}{|l|}{ Coeini (2) } \\
\hline Historis acheronta acheronta (Fabricius, 1775) & 0 & 1 & 1 & 0.2 & 4.2 \\
\hline Historis odius dious Lamas, 1995 & 5 & 2 & 7 & 1.4 & 16.7 \\
\hline \multicolumn{6}{|l|}{ Nymphalini (1) } \\
\hline Colobura dirce dirce (Linnaeus, 1758) & 2 & 6 & 8 & 1.6 & 16.7 \\
\hline \multicolumn{6}{|l|}{ Satyrinae (14) } \\
\hline \multicolumn{6}{|l|}{ Brassolini (4) } \\
\hline Caligo teucer teucer (Linnaeus, 1758) & 3 & 1 & 4 & 0.8 & 16.7 \\
\hline Caligo illioneus illioneus (Cramer, 1775) & 7 & 0 & 7 & 1.4 & 20.8 \\
\hline Catoblepia berecynthia berecynthia (Cramer, 1777) & 34 & 58 & 92 & 18.7 & 79.2 \\
\hline Opsiphanes invirae invirae (Hübner, [1808]) & 73 & 28 & 101 & 20.5 & 87.5 \\
\hline \multicolumn{6}{|l|}{ Morphini (2) } \\
\hline Morpho menelaus terrestris (Butler, 1866) & 1 & 0 & 1 & 0.2 & 4.2 \\
\hline Morpho helenor helenor (Cramer, 1776) & 1 & 3 & 4 & 0.8 & 16.7 \\
\hline \multicolumn{6}{|l|}{ Satyrini (8) } \\
\hline Cissia penelope (Fabricius, 1775) & 5 & 8 & 13 & 2.6 & 29.2 \\
\hline Cissia terrestris (Butler, 1867) & 33 & 9 & 42 & 8.5 & 37.5 \\
\hline Magneuptychia ocypete (Fabricius, 1776) & 16 & 5 & 21 & 4.6 & 33.3 \\
\hline Magneuptychia libye (Linnaeus, 1767) & 3 & 0 & 3 & 0.6 & 8.3 \\
\hline Hermeuptychia cf. atalanta (Butler, 1867) & 6 & 3 & 9 & 1.8 & 16.7 \\
\hline Taygetis laches laches (Fabricius, 1793) & 8 & 11 & 19 & 3.9 & 50.0 \\
\hline Taygetis echo echo (Cramer, 1775) & 0 & 1 & 1 & 0.2 & 4.2 \\
\hline \multirow[t]{2}{*}{ Taygetis sosis (Hopffer, 1874) } & 2 & 1 & 3 & 0.6 & 12.5 \\
\hline & 289 & 204 & 493 & & \\
\hline
\end{tabular}


Table 2. Abundance and richness of fruit-feeding butterflies recorded in Parque Agroecológico Buritirana (Maranhão state, eastern Brazilian Amazonia) by sampling year and subfamily.

\begin{tabular}{lcc}
\hline & Abundance & Richness \\
\hline First year & $\mathbf{2 5 5}$ & $\mathbf{2 5}$ \\
\hline Satyrinae & 157 & 12 \\
\hline Charaxinae & 37 & 6 \\
\hline Biblidinae & 53 & 4 \\
\hline Nymphalinae & 8 & 3 \\
\hline Second year & $\mathbf{2 3 8}$ & $\mathbf{2 3}$ \\
\hline Satyrinae & 163 & 12 \\
\hline Charaxinae & 37 & 6 \\
Biblidinae & 30 & 3 \\
Nymphalinae & 8 & 2 \\
\hline
\end{tabular}

74 (15\%) and Nymphalinae with 16 (3\%). Abundance per sample ranged from 5 to 67 individuals (mean $\pm S D=20.5 \pm$ 13.5), while richness per sample ranged from 4 to 16 species (mean $\pm \mathrm{SD}=7.6 \pm 3.2$ ).

Opsiphanes invirae invirae (Hübner, [1808]) (Satyrinae) was the most abundant species (101 individuals), followed by Catoblepia berecynthia berecynthia (Cramer, 1777) (Satyrinae) (92) and Hamadryas chloe rhea (Fruhstorfer, 1907) (Biblidinae) (57). These three species comprised approximately
$50 \%$ of the overall sample. Four species were recorded as singletons: Archaeoprepona demophoon demophoon (Hübner, [1814]) (Charaxinae), Historis acheronta acheronta (Fabricius, 1775) (Nymphalinae), Morpho menelaus terrestris (Butler, 1866) (Satyrinae) and Taygetis echo echo (Cramer, 1775) (Satyrinae), and one as a doubleton: Prepona laertes laertes (Hübner, [1811]) (Charaxinae). None of the species occurred in all sampling periods; the most abundant species, $O$. invirae invirae, occurred in 21 of the 24 samples.

During the first year (samples 1-12), we found no clear trend of abundance peaks, with an almost homogeneously distributed pattern, characterized by slight oscillations among samples. However, in the second year (samples 13-24), an abundance peak was observed in the transition between rainy and dry seasons (sample 14) (Figure 2). Regarding species richness, two distinct peaks were observed during the second year, one in the transition between rainy and dry seasons (sample 14) and the other in the early dry season (sample 16) (Figure 2). Circular analyses further demonstrated this pattern, as the abundance of fruit-feeding butterflies was uniformly distributed during the first year $(\mathrm{r}=0.066, \mathrm{Z}=$ $1.123, \mathrm{P}=0.325$ ) (Figure 3a), but showed a strong temporal structure during the second year $(r=0.348, Z=28.787$, $\mathrm{P}<0.01$ ) (Figure $3 \mathrm{~b}$ ). Similarly, the temporal distribution of species richness was uniform during the first year $(\mathrm{r}=$ $0.076, Z=0.491, P=0.612$ ) (Figure $3 c$ ), but showed a nonhomogeneous pattern during the second year $(r=0.219, \mathrm{Z}=$ 4.769, $\mathrm{P}=0.008$ ) (Figure 3d).

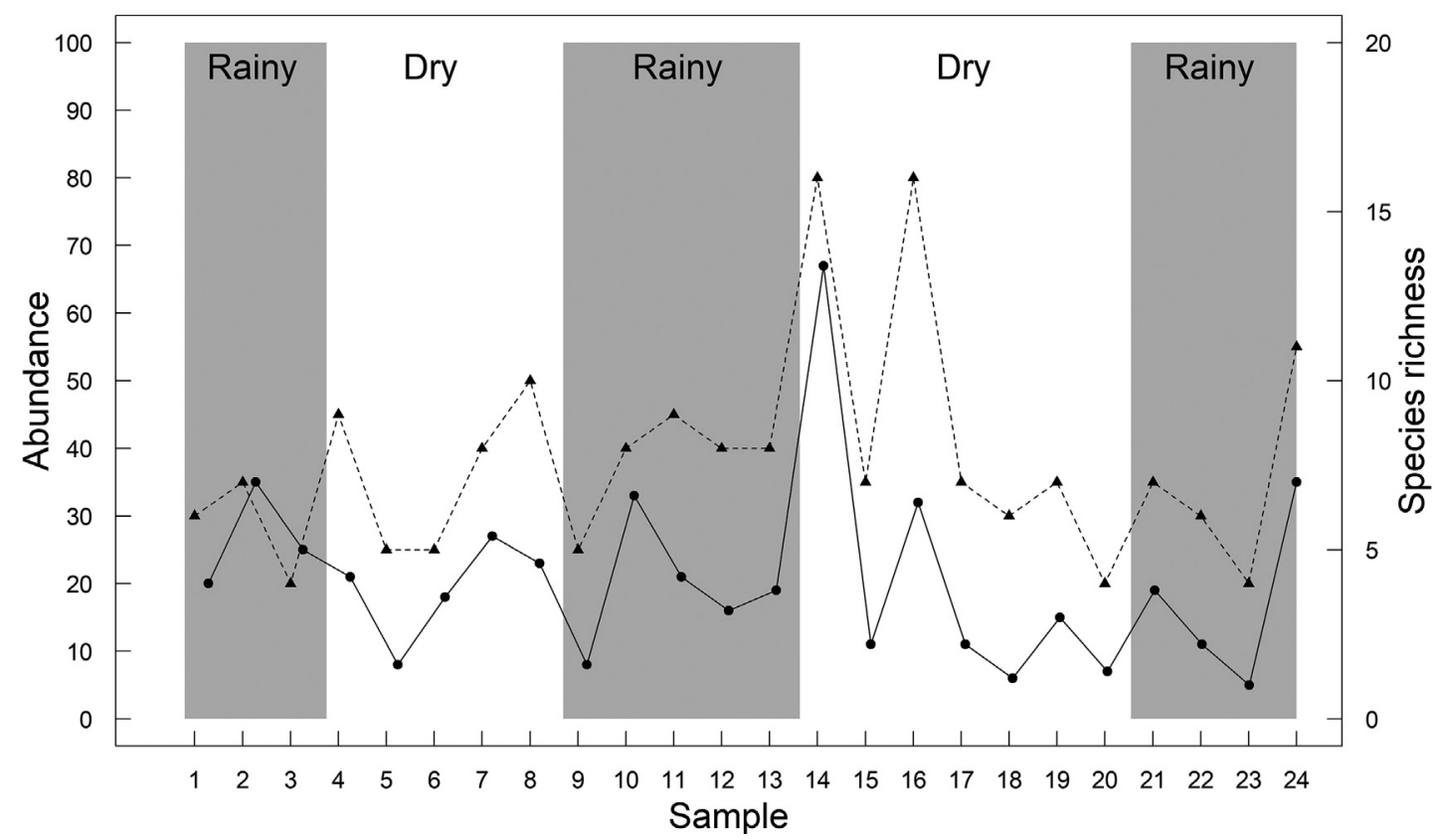

Figure 2. Temporal distribution of the abundance and species richness of fruit-feeding butterflies captured during two years in Parque Agroecológico Buritirana (Maranhão state, eastern Brazilian Amazonia). The solid line represents the variation in species abundance, and the dashed line represents the variation in species richness. 
A

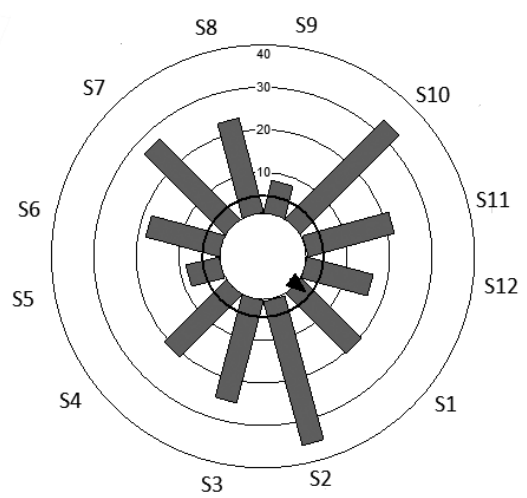

C

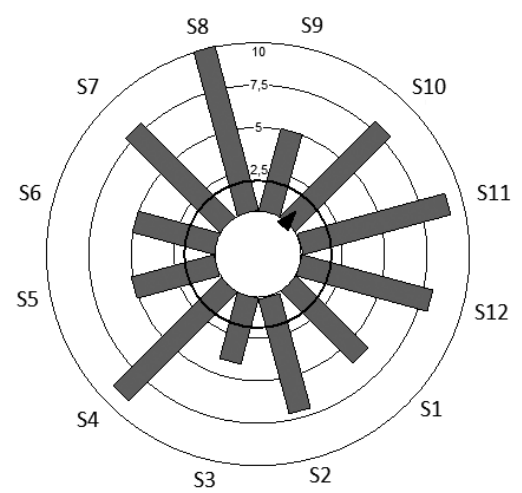

B

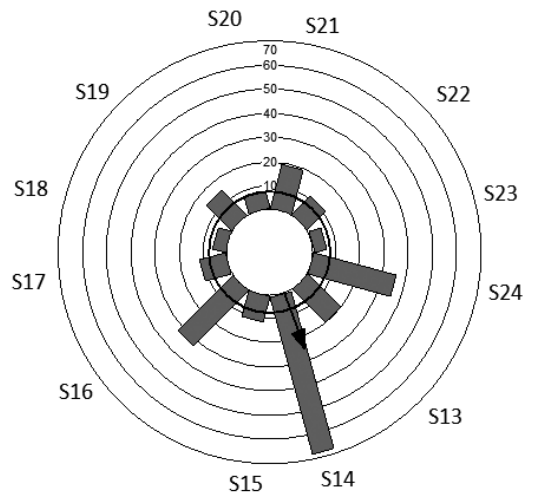

D

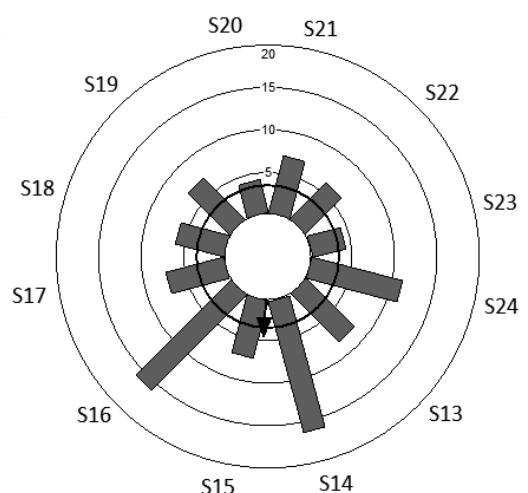

Figure 3. Circular histograms of the abundance and species richness of fruit-feeding butterflies during each of two sampling years in Parque Agroecológico Buritirana (Maranhão state, eastern Brazilian Amazonia). (A) abundance during the first year; (B) abundance during the second year; (C) species richness during the first year; (D) species richness during the second year. The arrows represent the average vector length $(r)$ and the bars represent the abundance or richness values in each sample. Samples are ranked from S1 to S24.

Species composition did not differ between the rainy and dry seasons. This result was maintained when evaluating both the Bray-Curtis (PERMANOVA: $\mathrm{F}=0.679 ; \mathrm{P}=0.587$; Figure 4 ) and Jaccard dissimilarity indices (PERMANOVA: $\mathrm{F}=1.171 ; \mathrm{P}=0.241)$. Of the 28 species sampled, 19 species $(67.8 \%)$ occurred in both seasons, four $(12.3 \%)$ were exclusive to the rainy season, and five (17.9\%) were exclusive to the dry season (Table 1).

Similar richness values were observed for the rainy and dry seasons. In fact, the $95 \%$ confidence intervals of the rarefaction and extrapolation curves almost entirely overlapped, demonstrating that there were no differences in richness between seasons (Figure 5). The estimated richness was 25.5 for the rainy season (23 species were actually collected), and 26.9 for the dry season (24 species were actually collected). Lastly, contrary to our expectations, we found that rainfall was not a good predictor of either butterfly abundance $(\mathrm{AIC}=202.460 ; \mathrm{t}$ value $=-0.193 ; \mathrm{P}$ $=0.849)$ or richness $(\mathrm{AIC}=143.248 ; \mathrm{t}$ value $=-0.529 ; \mathrm{P}$ $=0.602)$ (Figure 6$)$.

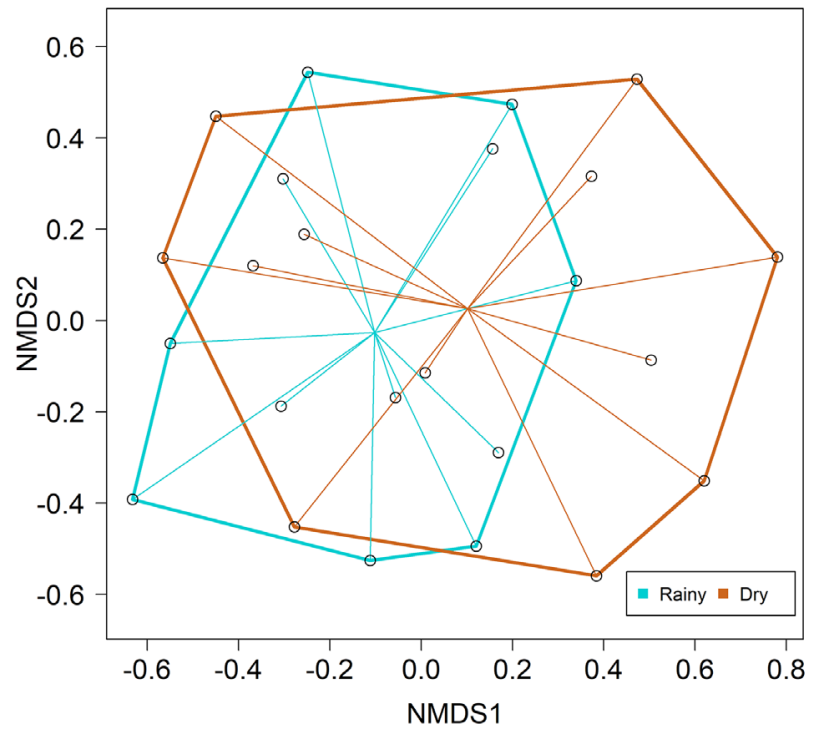

Figure 4. Non-metric multidimensional scaling (NMDS) using the Bray-Curtis dissimilarity index of fruit-feeding butterfly species composition in two seasons (rainy and dry) in Parque Agroecológico Buritirana (Maranhão state, eastern Brazilian Amazonia). Each point represents one sample. Results were qualitatively similar for the Jaccard index. This figure is in color in the electronic version. 

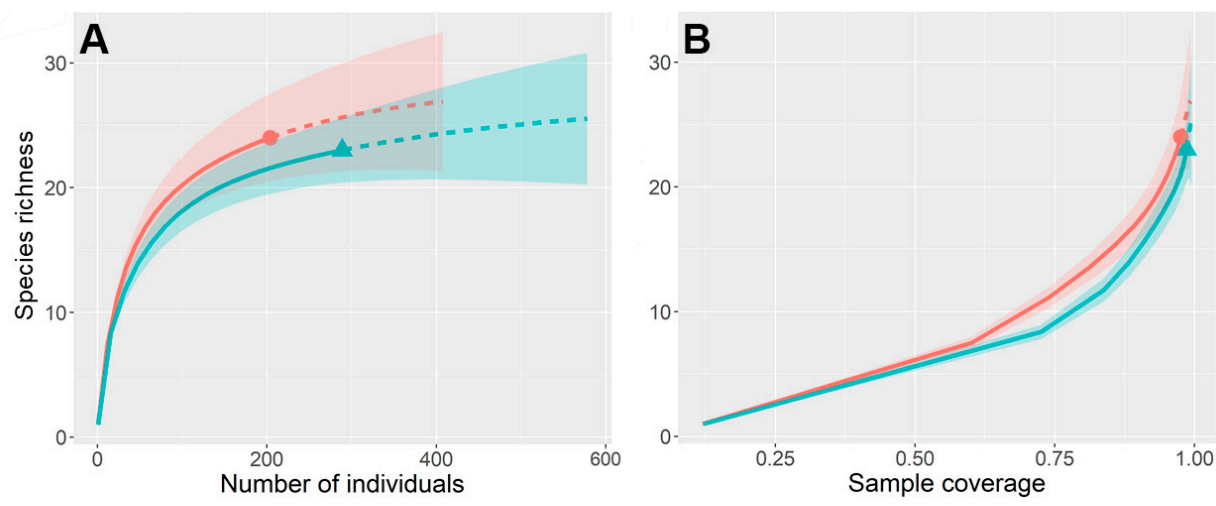

—interpolated $-\cdots$ extrapolated

- Rainy - - Dry

Figure 5. Rarefaction and extrapolation curves of fruit-feeding butterflies in two distinct seasons (rainy and dry) in Parque Agroecológico Buritirana (Maranhão state, eastern Brazilian Amazonia). (A) sample size-based curves; (B) coverage-based curves. Solid parts of the curves represent rarefaction; dashed curves represent extrapolation beyond observed samples. Shaded areas represent 95\% confidence intervals (bootstrapped). This figure is in color in the electronic version.
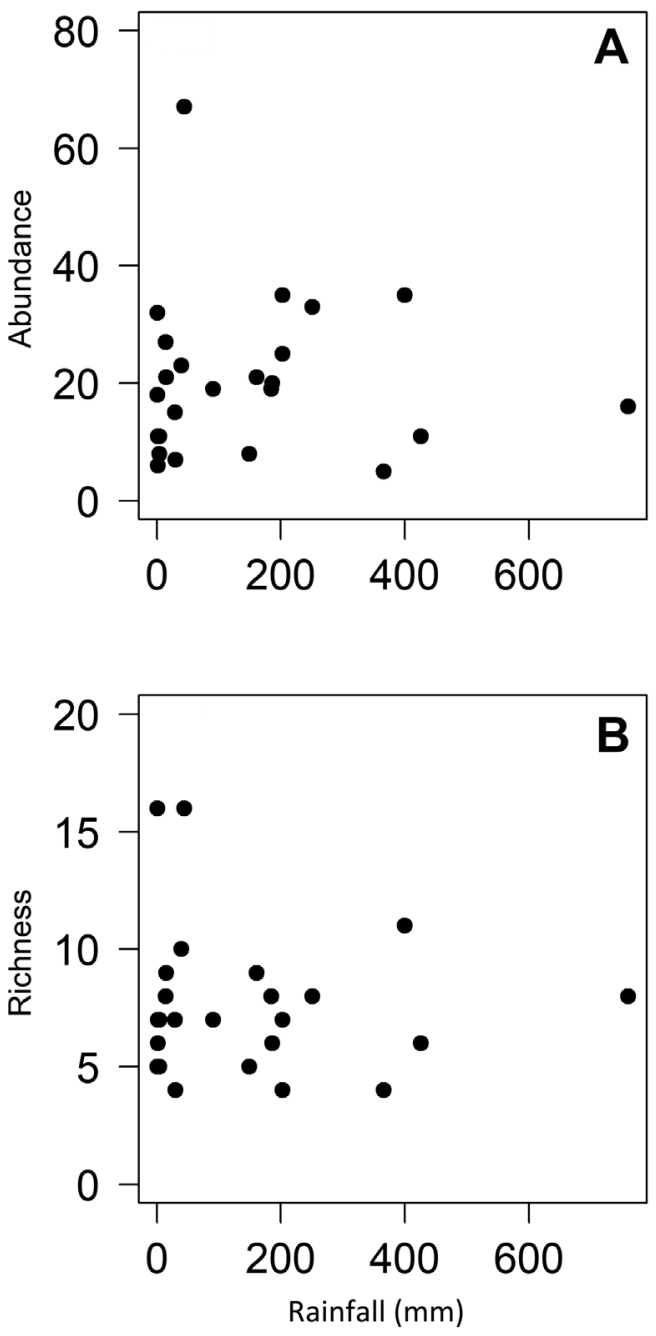

Figure 6. Relationship of monthly rainfall with species abundance (A), and species richness (B) of fruit-feeding butterflies in Parque Agroecológico Buritirana (Maranhão state, eastern Brazilian Amazonia).

\section{DISCUSSION}

The number of species sampled in the present study (28) was similar to the estimated richness, indicating that the sample was adequate to provide a fair representation of the local assemblage (Magurran 2004). However, both the observed and estimated richness were lower than those of other areas of the Brazilian Amazon (Barlow et. al. 2007; Barlow et al. 2008; Ribeiro and Freitas 2012), including its eastern portion (Ramos 2000; Teston and Silva 2017; Martins et al. 2017b). It is known that the guild of fruit-feeding butterflies tends to have fewer species in disturbed systems, and the overall species composition can be influenced by the vegetation structure and presence of food resources (Hamer et al. 2006; Ribeiro et al. 2008). The high abundance and richness of the subfamily Satyrinae is probably a consequence of the vegetation of $\mathrm{PAB}$ being composed mainly by the palm tree $A$. speciosa and other monocotyledons of the families Arecaceae and Poaceae (Pinheiro et al. 2013). Indeed, larvae of satyrines usually feed on monocotyledonous plants, specially grasses (Peña and Wahlberg 2008; Marín et al. 2011). The most abundant species in this study, $O$. invirae, is widely distributed throughout Brazil and well known as a pest of palms in the eastern Brazilian Amazon (Salgado-Neto and Silva 2011). Therefore, the high dominance of $O$. invirae and satyrines as a group is an indication that the study region has been impacted by anthropic disturbances that affected the original vegetation composition.

The observed peaks in abundance during the transition between the late rainy season and the early dry season contradict previous studies demonstrating that most insects are highly abundant at the beginning of the rainy season (Pinheiro et al. 2002; Da Silva et al. 2011). Furthermore, studies carried out in tropical environments have found higher butterfly richness at 
the end of the rainy season (Devries and Walla 2001; Pozo et al. 2008), while our study demonstrated a tendency toward higher richness at the beginning of the dry season. The expected pattern of overall lower species diversity during dry seasons is attributed mainly to the scarcity of food resources for larvae (Coley and Barone 1996; Novotny and Basset 1998), which puts an end to the annual cycles of most butterfly species, thereby decreasing species richness and abundance in periods of drought (Brown Jr. and Freitas 2000; Nobre et al. 2012). In fact, even if some resources are continuously available throughout the year, their quality may vary over time.

In the Baixada Maranhense, the abundance peak at the beginning of the dry season might be associated with the resources available during the previous rainy season, which may have led to a late development of larvae and to an increase in the number of adults. Alternatively, some authors have suggested that escape from natural enemies (a top-down force) is a crucial factor driving temporal dynamics in insects (Cosmo et al. 2019). However, the lack of studies regarding the temporal distribution of higher-trophic-level species (e.g. parasitoids and predators) in the Baixada Maranhense prevents further advances along this line of inquiry. Notably, non-uniform patterns of butterfly temporal distribution were observed only for the second year of sampling. This shows that long-term studies are essential to evaluate temporal patterns in butterflies, since short-term research may underestimate their temporal distribution (DeVries and Walla 2001).

We found that species composition and richness did not differ between the rainy and dry seasons, which might be explained by at least two factors. First, the vegetation in the study area is composed mainly of palm species, which are available throughout the year and do not show wide temporal variations in leaf or fruit availability (Peres 1994). As the larvae of Satyrinae, which dominated the butterfly assemblage, feed on monocotyledons, we might infer that food resources for immature butterflies do not represent an important biotic filter for species distribution over time. Similarly, food resources used by adults might follow the same pattern, with most fleshy fruits being available throughout both seasons. However, data on plant phenology in the study region is still scarce, and this issue should therefore be investigated and tested in the future. Second, the Amazon region lacks an intense dry season and has more stable climatic conditions compared to other biomes in Brazil, such as the Cerrado savannas and semi-arid Caatinga (Nobre et al. 2012; Freire Júnior and Diniz 2015). Indeed, although the Baixada Maranhense has a pronounced rainfall regime, which is easily observed through changes in the water level of floodplains and lakes, the dry season might not be a strong ecological filter affecting butterfly physiology and behavior. Therefore, both the indirect (via vegetation composition) and direct effects of seasonality on butterflies may not be severe enough to substantially change the species composition and richness.
Interestingly, the use of fermented baits is another factor potentially affecting the observed butterfly diversity (Freitas et al. 2014). To the best of our knowledge, no studies have assessed differences in the attractiveness of decomposed fruit baits between rainy and dry seasons. It is possible that other temporarily available resources in nature can compete more effectively with the quality and quantity of baits in the traps. For example, studies conducted in Nigeria with fruit pulp of the locust bean, Parkia biglobosa (Jacq.) R.Br. ex G. Don (Fabaceae), have shown that the amounts of nutrients (e.g. carbohydrates, proteins and fats) can vary from season to season (Nadro and Umaru 2004). Therefore, the product of bait fermentation may be more or less attractive to butterflies depending on the climatic conditions, as well as on the availability of other rotting fruits in the surrounding area.

Besides the absence of seasonal patterns, we found that butterfly abundance and richness were not directly influenced by rainfall. Teston and Silva (2017), studying some locations in the eastern Brazilian Amazon, indicated that the abundance and richness of fruit-feeding butterflies were negatively correlated with precipitation, while Nobre $e t$ al. (2012) demonstrated the opposite pattern in a semiarid area in northeastern Brazil. These results indicate that environmental variables, such as precipitation, may affect the fruit-feeding butterfly assemblages differently depending on the study site. This also reinforces the idea that the vegetation composition and other biotic factors (e.g. presence of natural enemies) might play a key role in the temporal distribution of fruit-feeding butterflies, a pattern previously demonstrated for other lepidopterans (Braga and Diniz 2018; Cosmo et al. 2019). Moreover, it is possible that rainfall is not an important driver of plant phenology in the Baixada Maranhense, so that the fruiting peaks of most angiosperm species are not synchronous with the rain cycle. This matter, however, remains to be investigated.

The temporal distribution of species may reflect several abiotic and biotic factors, such as rainfall, temperature and trophic interactions (bottom-up and top-down forces) (Silva et al. 2011; Freire Júnior and Diniz 2015; Cosmo et al. 2019). Although seasonality has been recorded for fruit-feeding butterfly assemblages from other sites in Brazil (e.g. Ribeiro et al. 2010; Nobre et al. 2012), the local vegetation type and anthropogenic disturbances in our study area may overshadow these temporal patterns. Indeed, as the studied assemblage is composed of generalist and opportunistic butterfly species, seasonality might not be as strong an ecological filter as previously considered. However, to what extent other factors drive the community structure of fruit-feeding butterflies in the eastern Amazon is a question yet to be explored. Therefore, the results reported and discussed here will serve as a beginning point for studies on the temporal diversity of butterflies in this poorly known region. 


\section{CONCLUSIONS}

As far as we know, this is the first study to analyze the temporal distribution of butterflies in the eastern extreme of the Amazon region. Although fruit-feeding butterflies showed a strong temporal structure during the second year of sampling, species composition and richness did not differ between the rainy and dry seasons. Furthermore, rainfall was not a good predictor of either butterfly abundance or richness. Our results contrast with those of previous studies that observed seasonal patterns in fruit-feeding butterfly assemblages, thereby indicating that other biotic and abiotic factors, such as vegetation structure and anthropogenic disturbances, may be the most important drivers of butterfly diversity in the Baixada Maranhense.

\section{ACKNOWLEDGMENTS}

We thank the students and researchers of the Laboratório de Ecologia e Sistemática de Insetos Polinizadores e Predadores, Departamento de Biologia (Universidade Federal do Maranhão) for their field assistance, and the administrative staff of the Instituto Formação for the use of their facilities in the study area. Special thanks to André Victor Lucci Freitas for his important contribution to specimen identification, Eduardo Fernando dos Santos for his comments on previous versions of the manuscript, and David Barros Muniz for the pictures and helping with the production of the map. We are grateful to Claudia Keller and two anonymous reviewers for helpful comments on the original version of the manuscript, and to Janet W. Reid for revising the English. This research was funded by Fundação de Amparo à Pesquisa do Estado do Maranhão (CBIOMA No. 02986/12). The first author and $\mathrm{MD}$ are grateful to Fundação de Amparo à Pesquisa do Estado de Sáo Paulo (grants 2002/13898-0, 2016/16185-8, 2016/50384-8 and 2017/23906-6) and Coordenação de Aperfeiçoamento de Pessoal de Nível Superior (CAPES). MD is also grateful to Conselho Nacional de Desenvolvimento Científico e Tecnológico (CNPq) (grants 305905/2012-0, 311083/2015-3 and 312190/2018-2).

\section{REFERENCES}

Barlow J.; Overal, W.L.; Araujo, I.S.; Gardner, T.A.; Peres, C.A. 2007. The value of primary, secondary and plantation forests for fruit-feeding butterflies in the Brazilian Amazon. Journal of Applied Ecology, 44: 1001-1012.

Barlow, J.; Araujo, I.S.; Overal, W.L.; Gardner, T.A.; Mendes, F.S.; Lake, I.R.; Peres, C.A. 2008. Diversity and composition of fruitfeeding butterflies in tropical Eucalyptus plantations. Biodiversity and Conservation, 17: 1089-1104.

Braga, L.; Diniz, I.R. 2018. Can Saturniidae moths be bioindicators? Spatial and temporal distribution in the Brazilian savannah. Journal of Insect Conservation, 22: 487-497.

Brown Jr., K.S.; Freitas, A.V.L. 2000. Atlantic forest butterflies: indicators for landscape conservation. Biotropica, 32: 934-956.
Chao, A.; Jost, L. 2012. Coverage-based rarefaction and extrapolation: standardizing samples by completeness rather than size. Ecology, 93: 2533-2547.

Checa, M.F.; Barragán, A.; Rodríguez, J.; Christman, M. 2013. Temporal abundance patterns of butterfly communities (Lepidoptera: Nymphalidae) in the Ecuadorian Amazonia and their relationship with climate. Annales de la Société entomologique de France, 45: 470-486.

Chesson, P. 2000. Mechanisms of maintenance of species diversity. Annual Review of Ecology and Systematics, 31: 343-366.

Chiquetto-Machado, P.I; Amorim, F.W.; Duarte, M. 2018. Longterm stability of the hawkmoth fauna (Lepidoptera, Sphingidae) in a protected area of Brazilian Atlantic Rain Forest. Journal of Insect Conservation, 22: 277-286.

Coley, P.D.; Barone, J.A. 1996. Herbivory and plant defenses in tropical forests. Annual Review of Ecology and Systematics, 27: 305-335.

Cosmo, L.G.; Nascimento, A.R.; Cogni R; Freitas, A.V.L. 2019. Temporal distribution in a tri-trophic system associates with Piper amalago L. in a tropical seasonal forest. Arthropod-Plant Interactions, 13: 1-6.

Costa Neto, J.P.; Barbieri, R.; Ibãnez, M.S.R.; Cavalcante, P.R.S.; Piorski, N.M. 2002. Limnologia de três ecossistemas aquáticos característicos da Baixada Maranhense. Boletim do Laboratório de Hidrobiologia, 14/15: 19-38.

D’Abrera, B. 1995. Butterflies of the Neotropical region: Nymphalidae (Partim) Pt. IV (Butterflies of the world). Hill House Publishers, Victoria, 151p.

Da Silva, N.A.P.; Frizzas, M.R.; De Oliveira, C.M. 2011. Seasonality in insect abundance in the 'Cerrado' of Goiás State, Brazil. Revista Brasileira de Entomologia, 55: 79-87.

Devries, P.J.; Murray, D.; Lander, R. 1997. Species diversity in vertical, horizontal, and temporal dimensions of a fruit-feeding butterflies community in an Ecuadorian rainforest. Biological Journal of the Linnean Society, 62: 343-364.

Devries, P.J.; Walla, T.R.; Greeley, H.F. 1999. Species diversity in spatial and temporal dimensions of a fruit-feeding butterfly community from two Ecuadorian rainforest. Biological Journal of the Linnean Society, 68: 333-353.

Devries, P.J.; Walla, T.R. 2001. Species diversity and community structure in neotropical fruit-feeding butterflies. Biological Journal of Linnean Society, 77: 1-15.

Ehrlich, P.R.; Raven, P.H. 1965. Butterflies and plants: a study in coevolution. Evolution, 18: 586-608.

Foley, J.A.; Asner, G.P.; Costa, M.H.; Coe, M.T.; DeFries, R.; Gibbs, H.K.; et al. 2007. Amazonia revealed: forest degradation and loss of ecosystem goods and services in the Amazon Basin. Frontiers in Ecology and the Environment, 5: 25-32.

Frederickson, M.E. 2006. The reproductive phenology of an Amazonian ant species reflects the seasonal availability of its nest sites. Oecologia, 149: 418-427.

Freire Júnior, G.B.; Diniz, I.R. 2015. Temporal dynamics of fruitfeeding butterflies (Lepidoptera: Nymphalidae) in two habitats in a seasonal Brazilian environment. Florida Entomologist, 98: 1207-1216. 
Freitas, A.V.L.; Iserhard, C.A.; Santos, J.P.; Carreira, J.Y.O.; Ribeiro, D.B.; Melo, D.H.A.; et al. 2014. Studies with butterfly bait traps: an overview. Revista Colombiana de Entomologia, 40: 209-218.

Garwood, K.; Lehman, R.; Carter, W.; Carter, G. 2009. Butterflies of Southern Amazonia. A photographic checklist of common species. 2nd ed. Tx., RiCalé Publishing, McAllen, 374p.

Grøtan, V.; Lande, R.; Chacon, I.A.; Devries, P.J. 2014. Seasonal cycles of diversity and similarity in a Central American rainforest butterfly community. Ecography, 37: 509-516.

Hamer, K.C.; Hill, J.K.; Benedick, S.; Mustaffa, N.; Chey, V.K.; Mohamed, M. 2006. Diversity and ecology of carrion and fruit-feeding butterflies in Bornean rainforest. Journal of Tropical Ecology, 22: 25-33.

Hsieh, T.C.; Ma, K.H.; Chao, A., 2019. iNEXT: iNterpolation and EXTrapolation for species diversity. $\mathrm{R}$ package version 2.0.19. (http://chao.stat.nthu.edu.tw/wordpress/software_download/ inext-online/). Accessed on 24/02/2019.

Huston, M. 1979. A general hypothesis of species diversity. The American Naturalist, 113: 81-101.

Kishimoto-Yamada, K.; Itioka, T. 2015. How much have we learned about seasonality in tropical insect abundance since Wolda (1988)? Entomological Science, 18: 407-419.

Kovach Computing Services, 2011. Oriana — circular statistics for windows. Kovach Computing Services, Pentraeth (https://www. kovcomp.co.uk/oriana/). Accessed on 20/02/2019.

Lucky, A.; Erwin, T.L.; Witman, J.D. 2002. Temporal and Spatial Diversity and Distribution of Arboreal Carabidae (Coleoptera) in a Western Amazonian Rain Forest. Biotropica, 34: 376-386.

MacArthur, R.H. 1964. Environmental factors affecting bird species diversity. The American Naturalist, 98: 387-397.

Magurran, A.E. 2004. Measuring biological diversity. 1st ed. Blackwell, Oxford, 264p.

Marín, M. A.; Peña, C.; Freitas, A.V.L.; Wahlberg, N.; Uribe, S.I. 2011. From the Phylogeny of the Satyrinae Butterflies to the Systematics of Euptychiina (Lepidoptera: Nymphalidae): History, Progress and Prospects. Neotropical Entomology, 40: $1-13$.

Martins, M.B.; Oliveira, T.G. 2011. Amazônia maranhense: Diversidade e conservação. 1st ed. Museu Paraense Emílio Goeldi, Belém, 328p.

Martins, L.P.; Araujo Junior, E.C.; Martins, A.R.P.; Colins, M.S.; Almeida, G.C.F.; Azevedo, G.G. 2017a. Butterflies of Amazon and Cerrado remnants of Maranhão, Northeast Brazil. Biota Neotropica, 17: 1-11.

Martins, L.P.; Araujo Junior, E.C.; Martins, A.R.P.; Duarte, M.; Azevedo, G.G. 2017b. Species diversity and community structure of fruit-feeding butterflies (Lepidoptera: Nymphalidae) in an eastern amazonian forest. Papéis Avulsos de Zoologia, 57: 481-489.

Moraes, B.C.; Costa, J.M.N.; Costa, A.L.; Costa, M.H. 2005. Variação espacial e temporal da precipitação no estado do Pará. Acta Amazonica, 35: 207-214.

Muniz, D.G.; Freitas, A.V.L.; Oliveira, P.S. 2012. Phenological relationships of Eunica bechina (Lepidoptera: Nymphalidae) and its host plant, Caryocar brasiliense (Caryocaraceae), in a Neotropical savanna. Studies on Neotropical Fauna and Environment, 47: 111-118.

Nadro, M.S.; Umaru H.A. 2004. Comparative chemical evaluation of locust bean (Parkia biglobosa) fruit pulp harvested during the dry and wet seasons. Nigeria Journal of Biotechnology, 15: 42-47.

Nobre, C.E.B.; Iannuzzi, L.; Schlindwein, C. 2012. Seasonality of fruit-feeding butterflies (Lepidoptera, Nymphalidae) in a Brazilian semiarid area. International Scholarly Research Network, 2012: 268159.

Nobre, C.P.; Costa, M.G.; Goto, B.T.; Gehring, C. 2018. Arbuscular mycorrhizal fungi associated with the babassu palm (Attalea speciosa) in the eastern periphery of Amazonia, Brazil. Acta Amazonica, 48: 321-329.

Novotny, V.; Basset, Y. 1998. Seasonality of sap-sucking insects (Auchenorrhyncha, Hemiptera) feeding on Ficus (Moraceae) in a lowland rain forest in New Guinea. Oecologia, 115: 514-522.

Oksanen, F.; Blanchet, G.; Friendly, M.; Kindt, R.; Legendre, P.; McGlinn, D.; et al., 2019. Vegan: community ecology package. R package version 2.5-4. (https://CRAN.R-project. $\mathrm{org} /$ package=vegan). Accessed on 05/01/2019.

Peña, C.; Wahlberg, N. 2008. Prehistorical climate change increased diversification of a group of butterflies. Biology Letters, 23: 274-278.

Pereira, L.A.; Sousa, A.L.; Cutrim, M.V.J.; Moreira, E.J. 2007. Características ecológicas do hábitat de Kinosternon scorpioides scorpioides Linnaeus, 1766 (Repitilia, Chelonia, Kinosternidae) no município de São Bento - Baixada Maranhense (Maranhão, Brasil). Boletim do Laboratório de Hidrobiologia, 20: 9- 14.

Pereira, R.C.C. 2012. Uma análise geossistêmica da alta bacia do Pericumá/MA. Revista Geonorte, 1: 284- 296.

Peres, C.A. 1994. Composition, density and fruiting phenology of arborescent palm trees in an Amazonian Terra Firme Forest. Biotropica, 26: 285-294.

Pinheiro, F.; Diniz, I.R.; Coelho, D.; Bandeira, M.P.S. 2002. Seasonal pattern of insect abundance in Brazilian cerrado. Austral Ecology, 27: 132-136.

Pinheiro, C.U.B.; Santos, V.M.; Ferreira, F.R.R. 2005. Uso de subsistência de espécies vegetais na região da Baixada Maranhense. Amazônia: Ciência \& Desenvolvimento, 1:235-250.

Pinheiro, C.U.B.; Araujo, N.A.; Arouche, G.C. 2010. Plantas úteis do Maranhão: região da Baixada Maranhense. 1st ed. Gráfica e Editora Aquarela, São Luís, 259p.

Pinheiro, C.U.B.; Araujo, N.A.; Arouche, G.C. 2013. Matas Ciliares: Recuperação e Conservação em áreas úmidas do Maranhão. 1st ed. Gráfica e Editora Aquarela, São Luís, 192p.

Pinheiro, J.; Bates, D.; DebRoy, S.; Sarkar, D. 2018. nlme: Linear and Nonlinear Mixed Effects Models. R package version 3.1137. (https://CRAN.R-project.org/package=nlme). Accessed on $25 / 02 / 2019$.

Pozo, C.; Martínez, A.L.; Bousquets, J.L.; Suárez, N.S.; Martínez, A.M., Fernandez, I.V.; Warren, A.D. 2008. Seasonality and phenology of the butterflies (Lepidoptera: Papilionoidea and Hesperoidea) of Mexico's Calakmul region. Florida Entomologist, 91: 407-422. 
R Core Team. 2019. R: A language and environment for statistical computing. R Foundation for Statistical Computing, Vienna, Austria. (www.R-project.org/). Accessed on 25/03/2019.

Ramos, F.A. 2000. Nymphalid butterfly communities in an amazonian forest fragment. Journal of Research on Lepidoptera 35: 29-41.

Rathcke, B.; Lacey, E.P. 1985. Phenological patterns of terrestrial plants. Annual Review of Ecology and Systematics 16: 179-214.

Ribeiro, D.B.; Prado, P.I.; Brown, K.S.; Freitas, A.V.L. 2008. Additive partitioning of butterfly diversity in a fragmented landscape: importance of scale and implications for conservation. Diversity and Distributions, 14: 961-968.

Ribeiro, D.B.; Prado, P.I.; Brown Jr, K.S.J.; Freitas, A.V.L. 2010. Temporal diversity patterns and phenology in fruit-feeding butterflies in the Atlantic forest. Biotropica, 42: 710-716.

Ribeiro, D.B.; Freitas, A.V.L. 2011. Large-sized insects show stronger seasonality than small-sized ones: a case study of fruit-feeding butterflies. Biological Journal of the Linnean Society, 104: 820827.

Ribeiro, D.B.; Freitas, A.V.L. 2012. The effect of reduce-impact logging on fruit-feeding butterflies in Central Amazon, Brazil. Journal of Insect Conservation, 16: 733-744.

Rydon, A. 1964. Notes on the use of butterfly traps in East Africa. Journal of the Lepidopterists' Society, 18: 51-58.

Salgado-Neto, G.; Silva, M.L. 2011. First report of parasitism on pupae of Opsiphanes invirae amplificatus Stichel (Lepidoptera, Nymphalidae) by Conura (Conura) maculata (Fabricius) (Hymenoptera, Chalcididae) in Rio Grande do Sul, Brazil. Revista Brasileira de Entomologia, 55: 285-286.

Sant'Anna, C.L.B.; Ribeiro, D.B.; Garcia, L.C.; Freitas, A.V.L. 2014. Fruit-feeding butterfly communities are influenced by restoration age in tropical forests. Restoration Ecology, 22: 1-6.

Scherrer, S.; Ferro, V.G.; Ramos, M.N.; Diniz, I.R. 2013. Species composition and temporal activity of Arctiinae (Lepidoptera: Erebidae) in two cerrado vegetation types. Zoologia, 30: 200-210.
Silva, N.A.P.; Frizzas, M.R.; Oliveira, M.C. 2011. Seasonality in insect abundance in the "Cerrado" of Goiás State, Brazil. Revista Brasileira de Entomologia, 55: 79-87.

Teston, J.A.; Silva, P.L. 2017. Diversity and seasonality of frugivorous butterflies (Lepidoptera, Nymphalidae) in the Tapajós National Forest, Pará, Brazil. Biota Amazônia, 7: 79-83.

Tonkin, J.D.; Bogan, M.T.; Bonada, N.; Rios-Touma, B.; Lytle, D.A. 2017. Seasonality and predictability shape temporal species diversity. Ecology, 98: 1201-1216

Uehara-Prado, M.; Brown Jr, K. S.; Freitas, A.V.L. 2005. Biological traits of frugivorous butterflies in a fragmented and a continuous landscape in the south Brazilian Atlantic Forest. Journal of the Lepidopterists' Society, 59: 96-106.

Uehara-Prado, M.; Brown Jr., K.S.; Freitas, A.V.L. 2007. Species richness, composition and abundance of fruit-feeding butterflies in the Brazilian Atlantic Forest: comparison between a fragmented and a continuous landscape. Global Ecology and Biogeography, 16: 43-54.

Valente, D.M.P.; Zenker, M.M.; Teston, J.A. 2018. Tiger-moths in savannas in Eastern Amazon: first assessment of diversity and seasonal aspects. Neotropical Entomology, 47: 842-851.

Winter, W.D. 2000. Basic techniques for observing and studying moth and butterflies. Memoirs of the Lepidopterists' Society, 5: 1-444.

Wolda, H. 1978. Seasonal fluctuations in rainfall, food and abundance of tropical insects. Journal of Animal Ecology, 47: 369-381.

Wolda, H. 1988. Insect seasonality: why? Review of Ecology and Systematics, 19: 1-18.

Zar, J.H. 1999. Biostatistical Analysis. 4th ed. Prentice Hall, New Jersey, 663p.

Zuur, A.F. 2009. Mixed Effects Models and Extensions in Ecology with $R$. 1st ed. Springer, New York, 574p.

RECEIVED: $25 / 03 / 2019$

ACCEPTED: $10 / 10 / 2019$

ASSOCIATE EDITOR: Fabrício B. Baccaro 